\title{
Ammonia migration from building materials to indoor air; technical, economical and environmental aspects
}

\author{
Bondar Krystsina*, Yalavaya Natallia \\ Department of Engineering Systems and Ecology, Brest State Technical University, 224017, Republic of Belarus
}

\begin{abstract}
The state-of-the-art of the problem of the migration of ammonia from building materials into the air of residential premises is discussed in the article. The international nature of the problem of ammonia pollution of indoor air in residential and office buildings was shown in the literature review. A method for the photometric determination of the content of nitrogen-containing compounds in the form of ammonium nitrogen with Nessler's reagent in concrete was propesd by the authors. This technique allows to control the ammonia content at a safe level. Also the method of potentiometric determination of the content of nitrogencontaining compounds for the analysis of additives for concrete was implemented by the authors. This analysis method allows prevent the use of additives that can potentially serve as a source of ammonia emissions during the exploitation of building materials.
\end{abstract}

\section{Introduction}

Since 2007 more than half of the world's population has residence in cities according to the information of The United Nations Department of Economic and Social Affairs. The Republic of Belarus takes 48th place in the world in terms of urbanization. The urban population in the country is $78.1 \%$. [1]. With the development of the economy and the growth of urbanization the time spent indoors by a person during the day is also increasing. Closed rooms of residential and administrative buildings have a peculiar microclimate. They are a reservoir of atmospheric air which contains in addition to the basic components a wide nomenclature of various chemical compounds often having a toxic effect on the human body. Pollutants can get into the air of rooms both from the outside with the influx of atmospheric air and from the inside - from the building materials of edifices, furniture and other objects inside the premises. A study of residential air conducted in 2009 by R. Gale and others showed that more than 400 components of various chemical structures from pesticides to hydrocarbons, alcohols and aldehydes can be isolated in its composition [2].

Today the main indoor air pollutants include carbon dioxide, carbon monoxide, nitrogen oxides, ammonia, benzene, formaldehyde, mold spores and bacteria. The report of the World Health Organization on the analysis of indoor air quality in educational institutions also includes trichlorethylene, tetrachlorethylene, polycyclic aromatic hydrocarbons, pinene, limonene (1-methyl-4isopropenylcyclohexene-1) [3].

Recently the problem of the presence of ammonia in the air in residential and office buildings has become especially important and this problem has become international and is relevant for countries located in different regions of the globe.

In the Russian Federation an excess of ammonia is most typical for structures being built in St. Petersburg. In 2011 the largest developers of the cities and others faced lawsuits due to a significant excess of the concentration of $\mathrm{NH}_{3}$ in new residential buildings. The measurements showed high ammonia content in the air of apartments up to $2.0 \mathrm{mg} / \mathrm{m} 3$ which is 50 times higher than the maximum permissible concentration. In 2014 due to the intense ammonia smell there were problems with the functioning of the Palace of Justice, and in 2016 the Center for Hygiene and Epidemiology of St. Petersburg discovered that the concentration of ammonia in the premises of the stadium under construction at CJSC Zenit-Arena in air exceeds the permissible level by 1.67 - 2.25 times [4-6]. The high ammonia content in the internal air of new buildings is also characteristic of the Ukraine. For example, in Kiev in a new gymnasium building an excess of permissible concentration of $\mathrm{NH}_{3}$ was recorded from 1.6 to 6.7 times [7].

For the Chinese construction industry the problem of the presence of ammonia in the air in residential premises is also relevant especially considering the world leadership of this country in the area of residential and administrative premises put into operation. $\mathrm{T}$. Lindgren in [8] describes a documented case of increased ammonia in a new office building in Beijing which led to deterioration in the well-being of personnel. The reason for $\mathrm{NH}_{3}$ getting into the air is the use of additives in concrete. Chinese authors in [9] name the use of urea-based additives in concrete (especially during construction work in winter) as the main source of ammonia entering the air in residential premises. According to them it takes more than 10 years to 
completely remove ammonia from concrete obtained using antifreeze additives!

The countries of the European Union also note the importance of ammonia as an indoor air pollutant. The article [10] provides monitoring data for 5 years of the ammonia content in the air of 14 administrative buildings in Finland. However, in a large-scale study of the air composition inside new energy-efficient residential buildings in 2016 in the Republic of Lithuania the authors concentrated their efforts mainly on volatile organic compounds: carbon dioxide and nitric oxide (IV). The ammonia content was not analyzed by them [11].

Undoubtedly, the issue of ammonia emissions from building materials is also important in the Republic of Belarus. The intensive use of concrete additives in the construction industry of our country can serve as a potential source of indoor air pollution. This can lead to significant economic losses since there are currently no effective and efficient methods for the rehabilitation of rooms with an existing ammonia emission problem.

In this regard, the practical task of determining ammonia in the form of ammonium nitrogen in cements and concrete, concrete mixes, as well as in additives for concrete, arises. Each of these analytical objects has its own specifics; therefore, a single, simple and reliable method for their chemical analysis does not exist. The authors of the article developed and tested various methods for determining ammonium:

-in cement and concrete with the help of the photometric method using the reaction with Nessler's reagent $[12,13]$, this technique was developed jointly with A.G.Gubskaya, T.I.Dziehtsiarova;

-in additives for concrete with the help of the potentiometric method using an ion-selective electrode [14].

\section{The method of photometric determination of the content of nitrogen-containing compounds in the form of ammonium nitrogen with Nessler's reagent in concrete}

The essence of the method is to extract nitrogencontaining compounds in the form of ammonium nitrogen from concrete by distilled water to obtain a colored solution with Nessler's reagent in an alkaline medium and then photometry.

To prepare a water extract of concrete from an analytical concrete sample $(10.00 \pm 0.01) \mathrm{g}$ is taken into a dry volumetric flask with a capacity of $250 \mathrm{ml}$ topped up with 100 to $150 \mathrm{ml}$ of distilled water, close the flask with a stopper and mix for $60 \mathrm{~min}$. using a stir bar or manually. The resulting suspension should be kept at room temperature for 18-20 hours, adjusted to the mark with distilled water, filtered into a dry conical flask with a capacity of $250 \mathrm{ml}$ through two folded blue ribbon filters. The first portions of the filtrate (about $10 \mathrm{ml}$ ) are discarded. The obtained aqueous extract of concrete is used to determine the content of nitrogen-containing compounds in the form of ammonium nitrogen with Nessler's reagent.

For analysis, solutions of Rochelle salt are prepared, as well as solutions for constructing a calibration graph (standard solutions). To prepare a solution of Rochelle salt $(33.0 \pm 0.1) \mathrm{g}$ of potassium sodium tartrate according to GOST 5845 is dissolved and then filtered in $100 \mathrm{ml}$ of hot distilled water.

To prepare a standard nitrogen solution (solution A) take $(0.2965 \pm 0.001) \mathrm{g}$ of ammonium chloride in accordance with GOST 3773, dried at a temperature of $(100-105)^{\circ} \mathrm{C}$ to a constant mass, put in a volumetric flask with a capacity of $1000 \mathrm{ml}$ and bring distilled water to the mark. The sample solution contains $0.1 \mathrm{mg}$ of nitrogen in $1 \mathrm{ml}$ of solution. A working sample solution (solution B) is prepared by diluting a stock sample solution (solution A) 1:10. The working sample solution contains $0.01 \mathrm{mg}$ of nitrogen in $1 \mathrm{ml}$ of solution.

To build a calibration graph $0,1,3,5.7$ and $9 \mathrm{ml}$ of working sample solution (solution B) are introduced into $100-\mathrm{ml}$ volumetric flasks which corresponds to 0.01 ; $0.03 ; 0.05 ; 0.07$; and $0.09 \mathrm{mg} \mathrm{NH}_{4}^{+}$, distilled water is brought to a volume of about $80 \mathrm{ml}, 3 \mathrm{ml}$ of a solution of Rochelle salt and $2 \mathrm{ml}$ of Nessler's reagent are added, distilled water are added to the mark and mixed.

After $10 \mathrm{~min}$ the optical density of the solutions is measured on a photoelectrocalorimeter with a blue light filter in a cuvette with an absorbing layer thickness of 30 $\mathrm{mm}$ relative to the blank experiment (zero solution).

According to the measurement results a graph is plotted, where the $\mathrm{NH}_{4}{ }^{+}$concentration (in $\mathrm{mg}$ ) along the abscissa axis in the sample solution and the optical density corresponding to them along the ordinate axis.

For the analysis $10 \mathrm{ml}$ of an aqueous extract of concrete is taken into a $100-\mathrm{ml}$ volumetric flask, distilled water is added to a volume of about $80 \mathrm{ml}, 3 \mathrm{ml}$ of a Rochelle salt solution and $2 \mathrm{ml}$ of Nessler's reagent are added, the mixture is brought to distillation with distilled water and stirred. The determination of the optical density of the analyzed solution is carried out similarly as described previously for constructing a calibration graph. The optical density of the control solution is subtracted from the optical density of the analyzed solution (correction for the purity of the filters and distilled water).

When processing the results of the analysis the mass fraction of ammonia nitrogen $\%$, in the analyzed concrete sample is calculated by the following formula:

$$
\mathrm{X}=\frac{\mathrm{a} \cdot 250 \cdot 100}{\mathrm{~m} \cdot 10 \cdot 1000},
$$

where $\mathrm{a}$ is the amount of ammonia nitrogen, found according to the calibration graph, $\mathrm{mg} ; \mathrm{m}$ is the mass of the sample, g.

The choice of the photometric method as the basis for determining the concentration of ammonium ions in concrete is justified by the following factors:

-the range of determination and sensitivity of the method allows you to control the content of $\mathrm{NH}_{4}{ }^{+}$ions in concrete with the required accuracy, 
-the performance of photometric determination is very simple, does not require highly qualified personnel and can be carried out in the conditions of the factory laboratory;

-photometry does not require expensive and difficult-to-maintain equipment;

-the analysis is highly expressive and can be performed in a relatively small period of time;

-the influence of extraneous ions of alkali and alkaline earth metals on the accuracy of determination is minimal.

\section{The methodology for potentiometric determination of the content of nitrogen-containing compounds in concrete additives}

Since concrete additives are often colored compounds it is not possible to use the photometric method to determine ammonium compounds in them. Therefore, the most suitable method for analyzing this type of object is the potentiometric method.

The essence of the method is to measure the electromotive force of the system, consisting of an ammonium-selective electrode and a reference electrode (silver chloride electrode). The ammonium selective electrode uses a hydrophobic gas permeable membrane to separate the sample solution from the solution filling the electrode. $\mathrm{NH}_{4}{ }^{+}$ions pass through the membrane and cause a change in the $\mathrm{pH}$ of the electrolyte solution on the other side of the membrane, which is captured by the internal $\mathrm{pH}$ electrode of the ammonium selective electrode.

For chemical analysis the laboratory ionomer I 160MP (TU RB 14694395.003-97), manufactured by OJSC Gomel Plant of Measuring Instruments was used. The composition of the electrochemical cell included: 1) an ammonium-selective electrode "Econ NH4" (TU 4215002-41541647-2006), manufacturer of the Scientific and Production Enterprise "Econix" (Moscow, Russian Federation); 2) silver chloride electrode EVL-1MZ.1 (TU 25-05.2181-77), manufacturer of OJSC Gomel Plant of Measuring Instruments.

According to the developed technique the ionomer is first calibrated by the calibration curve method in accordance with [15], and then the concentration of ammonium ions in the analyzed samples is determined, and the temperature of the analyzed samples and calibration solutions should not differ by more than $3^{\circ} \mathrm{C}$.

To prepare samples of additives for analysis a sample weighing $(2.00 \pm 0.01) \mathrm{g}$ is taken from an analytical sample, which is transferred into a beaker of at least 100 $\mathrm{ml} .50 \mathrm{ml}$ of distilled water are poured onto the sample and stirred with a glass rod. If there is an insoluble precipitate the resulting solution is filtered through a blue ribbon pleated filter. The resulting solution is poured into a $200 \mathrm{ml}$ volumetric flask and adjusted to the mark with distilled water. Before starting the analysis the prepared solution is kept for at least 2 hours.

To perform measurements in a beaker using a measuring cylinder make $45 \mathrm{ml}$ of the analyzed solution and measure the $\mathrm{pH}$ of the solution. If the hydrogen index of the solution is in the range from 3 to 8.5 , then 5 $\mathrm{ml}$ of a background solution of sodium nitrate with a molar concentration of $1 \mathrm{~mol} / \mathrm{dm}^{3}$ is added to the solution and stirred with a glass rod. If $\mathrm{pH}$ adjustment is required the prepared solutions of nitric acid or sodium hydroxide (each with a molar concentration of 1 $\mathrm{mol} / \mathrm{dm}^{3}$ ) are added dropwise to the analyzed solution from a $1 \mathrm{ml}$ pipette stirring until the $\mathrm{pH}$ of the solution corresponds to the required value from 3 to 8.5 . The volume of the added solution for regulating the $\mathrm{pH}$ of the solution (V) should not exceed $1 \mathrm{ml}$. Then $(5-\mathrm{V}) \mathrm{ml}$ of the background solution is added to the test solution and mixed with a glass rod. Measure the temperature of the solution, if necessary, the sample is thermostated. After that the ammonium-selective electrode and silver-silver electrode are immersed in the solution, the value of the emf of electrode system is measured. using an ionomer.

Processing of the results is as follows. For each measurement result according to the calibration graph, $\mathrm{pC}$ is found and the molar concentration of ammonium ions $\mathrm{C}, \mathrm{mol} / \mathrm{dm}^{3}$, is calculated by the formula:

$$
\mathrm{C}=10^{-\mathrm{pC}}
$$

The mass concentration of ammonium ions (X) in the analyzed additive, $\mathrm{mg} / \mathrm{kg}$, is determined by the formula:

$$
\mathrm{X}=\frac{\mathrm{C} \cdot \mathrm{M}\left(\mathrm{NH}_{4}^{+}\right) \cdot \mathrm{V} \cdot 10^{3}}{\mathrm{~m} \cdot 10^{-3}}=\frac{\mathrm{C} \cdot 3,608 \cdot 10^{6}}{\mathrm{~m}}
$$

where $\mathrm{M}\left(\mathrm{NH}_{4}{ }^{+}\right)=18.04 \mathrm{~g} / \mathrm{mol}$ is molar mass of ammonium ions; $\mathrm{m}$ is the mass of the sample taken for analysis of the additive, $\mathrm{g} ; \mathrm{V}=200 \mathrm{ml}$ is the volume of the analyzed sample.

The technique developed by the authors was tested at the enterprises of the construction industry of Brest region. Some results of the determination of ammonium ions in concrete additives conducted by the authors are shown in table 1 .

Table 1. The results of determining the content of ammonium ions in concrete additives

\begin{tabular}{ccccc}
\hline Additive & $\begin{array}{c}\text { Type of } \\
\text { concrete } \\
\text { additive }\end{array}$ & $\mathrm{pH}$ & $\begin{array}{c}\text { Temperature, } \\
{ }^{\circ} \mathrm{C}\end{array}$ & $\begin{array}{c}\text { Mass } \\
\text { concentration of } \\
\text { ammonium ions } \\
(\mathrm{X}), \mathrm{mg} / \mathrm{kg}\end{array}$ \\
\hline $\begin{array}{c}\text { Sample } \\
1\end{array}$ & $\begin{array}{c}\text { Plasticizer } \\
\text { (I group) }\end{array}$ & 7,18 & 21,4 & 116,0 \\
\hline $\begin{array}{c}\text { Sample } \\
2\end{array}$ & $\begin{array}{c}\text { Plasticizer } \\
\text { (I group) }\end{array}$ & 7,14 & 21,3 & 160,2 \\
\hline $\begin{array}{c}\text { Sample } \\
3\end{array}$ & $\begin{array}{c}\text { Plasticizer } \\
\text { (I group) }\end{array}$ & 7,26 & 21,2 & 134,7 \\
\hline $\begin{array}{c}\text { Sample } \\
4\end{array}$ & $\begin{array}{c}\text { Plasticizer } \\
\text { (I group) }\end{array}$ & 5,22 & 21,3 & 258,5 \\
\hline $\begin{array}{c}\text { Sample } \\
5\end{array}$ & $\begin{array}{c}\text { Plasticizer } \\
\text { (II group) }\end{array}$ & 9,89 & 21,3 & 490,0 \\
\hline $\begin{array}{c}\text { Sample } \\
6\end{array}$ & $\begin{array}{c}\text { Plasticizer } \\
\text { (I group) }\end{array}$ & 6,35 & 21,2 & 157,3 \\
\hline $\begin{array}{c}\text { Sample } \\
7\end{array}$ & $\begin{array}{c}\text { Plasticizer } \\
\text { (I group) }\end{array}$ & 4,62 & 21,3 & 141,5 \\
\hline
\end{tabular}




\begin{tabular}{|c|c|c|c|c|}
\hline $\begin{array}{c}\text { Sample } \\
8\end{array}$ & $\begin{array}{l}\text { Plasticizer } \\
\text { (IV } \\
\text { group) }\end{array}$ & 7,45 & 19,3 & not detected \\
\hline
\end{tabular}

The choice of the potentiometric method as the basis for determining the concentration of ammonium ions in concrete additives is justified by the following factors:

-the range of determination and sensitivity of the method allows to control the content of $\mathrm{NH}_{4}{ }^{+}$ions in additives with the required accuracy,

-the performance of potentiometric determination is very simple, does not require highly qualified personnel and can be carried out in the conditions of the factory laboratory;

-potentiometry does not require expensive and difficult to maintain equipment;

-toxic and expensive auxiliary reagents are not used for potentiometric determination of ammonium ions;

-the analysis is highly expressive and can be performed in a relatively small period of time;

-unlike spectrophotometric analysis for potentiometric determination, the intrinsic color of the concrete additive is not significant.

\section{Conclusions}

The developed methods for the determination of ammonium compounds in building materials make it possible to create a reliable barrier for the emission of ammonia into the indoor air of residential and administrative buildings. First, using the potentiometric control method, it is possible to exclude the use of potentially dangerous additives in concrete. Second, the photometric method allows the detection of ammonia in cements (concrete) prior to the stage of their use at construction sites. In our opinion it is a comprehensive, two-staged approach to the determination of ammonia both in the building materials themselves and in raw materials for their production that helps to prevent an undesirable situation with the subsequent emission of $\mathrm{NH}_{3}$ from building materials during the operation of an edifice.

\section{References}

1. World Urbanization Prospects: The 2018 Revision (2018) New York, United Nations, Department of Economic and Social Affairs, Population Division

2. Gale, R.W. Cranor, W.L., Alvarez, D.A., Huckins, J.N., Petty, J.D., Robertson, G.L. (2009) Semivolatile Organic Compounds in Residential Air along the Arizona-Mexico Border. Environ. Sci. Technol., 43 (9): 3054-3060.

3. Окружающая среда в школах: политика и текущее состояние: отчет ВО3 (2015) Европейское региональное бюро ВО3, Копенгаген. (in Russian)

4. На строящемся стадионе «Зенита» обнаружили аммиак и формальдегид (2016) Фонтанка: Петербургская интернет газета http://www.fontanka.ru/2016/11/17/086/ (in Russian)
5. Сотрудники Горсуда не выдержали запаха аммиака (2014) Фонтанка: Петербургская интернет газета http://www.fontanka.ru/2014/02/04/149/ (in Russian)

6. Фокин, Д.С. (2013) Проблема повышенного содержания аммиака в воздухе жилых помещений. Коммунальная гигиена, 12 (249): 33-34. (in Russian)

7. ЧП районного масштаба. Формальдегид, фенол и аммиак детям вместо знаний (2015) РИА Новости дираина http://rian.com.ua/analytics/20150923/374140989.ht $\mathrm{ml}$ (in Russian)

8. Lindgren, T. (2010) A case of indoor air pollution of ammonia emitted from concrete in a newly built office in Beijing. Building and Environment, 45 (3): 596-600.

9. Bai, Z., Dong, Y., Wang, Z., Zhu, T. (2006) Emission of ammonia from indoor concrete wall and assessment of human exposure. Environment International, 32 (3): 303-311.

10. Salonen, H.J., Pasanen, A.L., Lappalainen, S.K., Riuttala, H.M., Tuomi, T.M., Pasanen, P.O., Bäck, B.C., Reijula, K.E. (2009) Airborne concentrations of volatile organic compounds, formaldehyde and ammonia in Finnish office buildings with suspected indoor air problems. J Occup Environ Hyg., 6(3): 200-209.

11. Kauneliene, V., Prasauskas. T., Krugly. E., Stasiulaitine, I., Čiužas, D., Šeduikyté, L., Martuzevičius, D. (2016) Indoor air quality in low energy residential buildings in Lithuania. Building and Environment, 108: 63-72.

12. Рекомендации по определению безопасного содержания азотсодержащих соединений в цементе и бетоне (2015) Минск, РУП «Институт НИИСМ» (in Russian)

13. Халецкая, К.В., Яловая, Н.П., Яловая Ю.С. (2015) Аммиак и его соединения в железобетонных изделиях: обзор аналитических методик и результаты потенциометрического и фотомерического определения. Вестн. Полоц. гос. ун-та. Сер. F, Строительство. Прикладные науки, 8: 88-96. (in Russian)

14. Бондарь, К.В., Яловая, Н.П. (2017) Использование потенциометрического метода для контроля содержания ионов аммония в добавках для бетона с целью предотвращения миграции аммиака в воздух помещений. Вестн. Брест. гос. техн. ун-та, 1 (103): 131-134. (in Russian)

15. Методика выполнения измерений массовой концентрации ионов аммония в воде и водных растворах потенциометрическим методом с помощью ионоселективных электродов «ЭкомNH4». (2007) Москва, 2007. (in Russian) 